\title{
Application of Isotopes in Studying Lake Water - Groundwater Interactions in Parts of Tumkur District of Karnataka
}

\author{
M.S. RAO ${ }^{1}$, L SAMPATH KUMAR ${ }^{2}$, GOPAL KRISHAN ${ }^{\star 1}$, C. RANGARAJ ${ }^{2}$ and C P KUMAR ${ }^{1}$ \\ ${ }^{1}$ National Institute of Hydrology, Roorkee - 247667 (Uttarakhand), India. \\ ${ }^{2}$ Sri Siddhartha Institute of Technology, Tumkur-572105 (Karnataka), India.
}

http://dx.doi.org/10.12944/CWE.11.3.09

(Received: October 18, 2016; Accepted: November 03, 2016)

\begin{abstract}
In the present study, to demonstrate use of combined isotopic and salinity mapping in understanding local scale groundwater-surface water conditions the water samples were collected from 4 nos. of defined lakes (Kadaba, Belavatta, Pura and Nittur); groundwater samples were collected from shallow hand pumps/tube wells along the periphery of the lakes. The rain samples were also collected. The lake water appears to get enriched in its isotopic composition mainly due to evaporation in this region. Lake water salinities are lower compared to nearby groundwater salinity. The flow of groundwater, recharged at Nittur lake, continues to its downstream at least till Pura. Increase in salinity of groundwater is seen between the points Pura-groundwater \& surface water (may be due to dissolution of sub-surface soil). The groundwater sampled at Belavatta is found to be recharged from local precipitation and not from surface body. The water body (Kadaba) is getting filled mainly due to precipitation and to some extent due to runoff from the upper reach of water body. There is a strong link between lake water-groundwater (e.g. site Pura) and groundwater-lake water (e.g. Site Kadaba). Therefore, this procedure is expected to radically increase the accountability of usage and help in planning of suitable ground water supply and would provide a holistic approach to promote maximum agricultural output and industrial growth.
\end{abstract}

Keywords: Surface water, groundwater, lakes, isotopes, salinity, Tumkur, Karnataka.

\section{INTRODUCTION}

It is apparent that development of either of land and water resources affects the quantity and quality of the other as surface water and groundwater interactions take many forms and can cause changes in quality of each other. Thus, effective land and water management requires a clear understanding of the linkages between groundwater and surface water and isotopes can be potential tool for this. The composition of hydrogen and oxygen isotopes in water bodies vary in time and space due to various hydrological processes. Hence, the origin and the circulation of water can be traced by the hydrogen and oxygen isotope abundance ${ }^{1}$. Various studies have been carried out by the researchers by using isotopes and hydro-chemistry in surface watergroundwater interactions ${ }^{2-10}$.

The isotopic ratios of lake water are, generally similar to those of river water flowing into the lake. In particular case, such as no outlet river, the isotopic ratios of lake water are modified through evaporation as well as isotopic exchange with atmospheric moisture. In lakes, water supply by inflows as well as precipitation on the lake is balanced with sum of outflow (including leakage from the bottom) and evaporation. If the rate of evaporation is considerable, roughly more than a few percent of the outflow, the modification becomes significant, and the isotopic ratios of lake water are generally heightened. In such case, rate of changes in $\mathrm{d}^{18} \mathrm{O}$ is 
controlled by relative extent of the evaporation and the isotopic exchange. Craig and Gordan (1965) ${ }^{11}$ discussed theoretically that the evaporation and the isotopic exchange take place at the same time and the model given by them has been applied to many lake studies (e.g. Sakai and Matsubaya, 1977) ${ }^{12}$.

There is a series of lakes on the left bank of the Hemavathi canal within a stretch of $20 \mathrm{~km}$ from the Tumkur city and the lakes are both defined \& undefined ${ }^{13}$. The temporal and spatial variation of rainfall is uneven in the area and there are instances when the area has not received rainfall for many years in succession. These lakes lie in semi-arid region with high evaporation rate so ground water recharge seems to be the best means of water storage. The rocks are weathered and fractured having multiple dykes. The lakes lie in the hard rock region and the underlying rock is fractured ${ }^{13}$. It, therefore, becomes necessary to determine the direction and quantity of groundwater flow. In hardrock region, analysis is not as simple as in alluvial region and required specialized technique like isotope method as the conventional methods of analysis may not be useful. For this purpose, the environmental isotope technique was used to trace the ground water flow path between the series of lakes.

\section{METHODOLOGY}

The water samples were collected from 4 nos. of defined lakes (Kadaba, Belavatta, Pura and Nittur) and groundwater samples were collected from shallow hand pumps/tube wells along the periphery of the lakes as per the details shown in table 1. The rain samples were also collected. The latitude, longitude, elevation and Electrical Conductivity of all the samples were recorded during the sampling.

Sample collection was followed by stable isotope analysis in the laboratory of National Institute of Hydrology (NIH), Roorkee.

Dual Inlet Isotope Mass Spectrometer is used for calculating $d^{18} \mathrm{O}$ values of all collected samples and hence interpreting the source of ground water along with canal and ground water interpretation.

\section{RESULTS AND DISCUSSION}

The isotopic composition $\left(\mathrm{d}^{18} \mathrm{O}\right)$ was found in the groundwater in the range of -2.97 to $+4.85 \%$ o and surface water in the range of -0.8 to $4.63 \%$ (Table 2).

Groundwater in the lower half of the region i.e. L2G2: $-2.97 \%$, L1G2: $-2.86 \%$, and L1G1: $-2.9 \%$. The initial isotopic composition of water has to be lighter than $-2.97 \%$ s say, $-3.0 \%$ (or equal to $-2.97 \%$, only if, evaporation takes place during recharge ultrafast recharge process). It is probably due to evaporation that lake water appears to get enriched in its isotopic composition as observed at sites: L2S1, L3S1, L1S1 and L4S1 values;- $0.8 \%$ o, $+3.13 \%$, $+4.47 \%$ ond $+4.63 \%$, respectively.

In general, lake water salinity is lower compared to the nearby groundwater. Lake water salinity varies from $390 \mathrm{mS} / \mathrm{cm}$ to $610 \mathrm{mS} / \mathrm{cm}$ whereas, groundwater salinity varies from $430 \mathrm{mS} /$ $\mathrm{cm}$ to $1350 \mathrm{mS} / \mathrm{cm}$. Sample collected from lake site L4S1 although indicates a good extent of evaporation $\left(\mathrm{d}^{18} \mathrm{O}=4.63 \%\right.$ ) still its salinity $(\mathrm{EC})$ is $390 \mathrm{mS} / \mathrm{cm}$. This means, in absence of evaporation the expected salinity would be much lower than $390 \mathrm{mS} / \mathrm{cm}$.

Thus, initial composition of fresh water (not subjected to evaporation, mixing and contamination) can be considered to be EC $<390 \mathrm{mS} / \mathrm{cm}$ and $\mathrm{d}^{18} \mathrm{O}$ data $\sim-3.0 \%$. Using this initial value, formation of surface water and groundwater can be evaluated.

L3G1 falls on down-side of $L 4$ with its $\mathrm{d}^{18} \mathrm{O}$ $(4.85 \%)$ and EC $(430 \mathrm{mS} / \mathrm{cm})$ marginally higher than $\mathrm{L} 4 \mathrm{~S} 1\left(\mathrm{~d}^{18} \mathrm{O}=4.63 \%\right.$ and $\left.\mathrm{EC}=390 \mathrm{mS} / \mathrm{cm}\right)$. This enrichment (by $\sim 5 \%$ above $L 4$ that has $\mathrm{d}^{18} \mathrm{O}=4.65$ $\%$ ) might have resulted into $10 \%$ enrichment in its salinity. Both these waters are highly evaporated with respect to original water. $d^{18} \mathrm{O}$ of $\mathrm{L} 3 \mathrm{~S} 1$ is $3.13 \%$ 。 which is lighter than L3G1 water $\left(\mathrm{d}^{18} \mathrm{O}=4.85 \%\right.$ ) but enriched compared to initial composition-3.0\%. Such water can be formed by mixing of $22 \%$ of fresh water of $-3 \%$ and $78 \%$ of $4.85 \%$ isotopic composition groundwater. Thus, flow of groundwater recharged at $L 4$ continues to its downstream at least till L3. Dissolution of sub-surface salts probably have caused increase in salinity of groundwater between 
Table 1: Sample collection detail

\begin{tabular}{|c|c|c|c|c|c|c|}
\hline \begin{tabular}{|l}
$5 \mathrm{r}$ \\
$\mathrm{now}$
\end{tabular} & Lake Name & $\frac{\text { Sample }}{\text { sepresentation }}$ & Lat: Lomg & Elevation fm & $\begin{array}{l}\text { Date \& Trme of } \\
\text { Sampling }\end{array}$ & Comments \\
\hline \multirow[t]{2}{*}{1} & \multirow{2}{*}{$\begin{array}{l}\text { KADABA } \\
\text { (Defnertake) }\end{array}$} & \multirow[t]{2}{*}{$E_{1}, S_{1}$} & \multirow{2}{*}{$\begin{array}{l}\mathrm{N}_{1} 3^{c} \pm 4^{\prime} 35,2^{n} \\
E-6^{\circ} 5^{\prime} 57,2^{\prime \prime}\end{array}$} & \multirow[t]{2}{*}{772} & $24-04-2012$ & \multirow[t]{2}{*}{ Surface mater sample } \\
\hline & & & & & $10: 05$ A.1. & \\
\hline & & \multirow[t]{2}{*}{$\mathrm{I}=1, \mathrm{G}_{1}$} & \multirow[t]{2}{*}{$\begin{array}{l}113^{\circ} 14^{\prime} 42.1^{\prime \prime} \\
E-6^{\circ} 53^{3} 40.3^{\prime \prime}\end{array}$} & \multirow[t]{2}{*}{785} & $24-04-2012$ & \multirow[t]{2}{*}{$\begin{array}{l}\text { Doreten sample Goom } \\
\text { frin } 1\end{array}$} \\
\hline & & & & & 10:31A34 & \\
\hline & & \multirow[t]{2}{*}{ I.1, G2 } & \multirow[t]{2}{*}{$\begin{array}{l}N 13^{\circ} 15^{\prime} \cdot 2.2^{\prime \prime} \\
E-6^{\circ} 5^{\prime} 44.1^{n}\end{array}$} & \multirow[t]{2}{*}{-90} & $24-04-2012$ & \multirow[t]{2}{*}{ 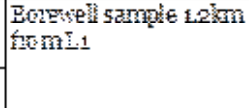 } \\
\hline & & & & & $10: 45 A .21$ & \\
\hline \multirow[t]{2}{*}{2} & \multirow{2}{*}{$\begin{array}{l}\text { BELAVATIA } \\
\text { fDeined lake) }\end{array}$} & \multirow[t]{2}{*}{$\mathrm{E} z, \mathrm{~S}_{1}$} & \multirow{2}{*}{ 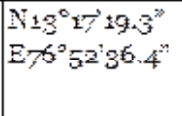 } & \multirow[t]{2}{*}{77} & $24-04-2012$ & \multirow[t]{2}{*}{ Surf ace tiater sampie } \\
\hline & & & & & $10: 58$ A M & \\
\hline & & \multirow[t]{2}{*}{$\mathrm{E}, \mathrm{z}, \mathrm{G} 1$} & \multirow{2}{*}{$\begin{array}{l}\text { N } 13^{\circ} 1720.5^{\prime \prime} \\
86^{\circ} 52^{2}-78^{\prime \prime}\end{array}$} & 781,5 & $24-04-2012$ & \multirow[t]{2}{*}{ Grotm dvater sample } \\
\hline & & & & & $1: 12 \pm M$ & \\
\hline & & \multirow[t]{2}{*}{$\mathrm{L}, \mathrm{z}, \mathrm{G} \underline{\mathrm{z}}$} & \multirow{2}{*}{$\begin{array}{l}\mathrm{N} 13^{\circ} 18^{\prime} 30 . \mathrm{s}^{\circ} \\
\mathrm{E}, \mathrm{S}^{\circ} 5 \pm 45.1^{\circ}\end{array}$} & \multirow[t]{2}{*}{$8 \pm 4.4$} & $24-04-2012$ & \multirow[t]{2}{*}{ Grothidvater sample } \\
\hline & & & & & 1s:29A.M1 & \\
\hline \multirow[t]{4}{*}{3} & \multirow{2}{*}{$\begin{array}{l}\text { PURA folefined } \\
\text { laike) }\end{array}$} & \multirow[t]{2}{*}{$\mathrm{I}, 3, \mathrm{~S}_{1}$} & \multirow{2}{*}{$\begin{array}{l}113^{\circ} 18: 56.0^{*} \\
876^{\circ} 5135.4^{\prime \prime}\end{array}$} & 825 & $24-04-2012$ & \multirow[t]{2}{*}{ Surface tiater sampie } \\
\hline & & & & & $11+39$ A.MI & \\
\hline & & \multirow[t]{2}{*}{$E_{3,} G_{1}$} & \multirow{2}{*}{$\begin{array}{l}\mathbb{N}_{23^{\circ}} \pm 9^{\circ} 16.2^{7} \\
876^{\circ} 5 \pm 39 \cdot 7^{*}\end{array}$} & \multirow[t]{2}{*}{794} & $24-04-2022$ & \multirow[t]{2}{*}{ Grománitur sample } \\
\hline & & & & & 12:55A.M & \\
\hline 4 & NTITER & $L_{4: 51}$ & $\mathrm{~N}_{23^{\circ}} 1930.7$ & 503 & $24-04-2022$ & Suf ace vater sampie \\
\hline & & & & & 12.01 F.M & \\
\hline
\end{tabular}

Table 2: Variation in isotopic composition $\left(\delta^{18} \mathrm{O} \%\right.$ ) and salinity in the study area

\begin{tabular}{lcc}
\hline Sample & $\delta^{18} \mathbf{O}(\%)$ & EC $(\boldsymbol{\mu S} / \mathbf{c m})$ \\
\hline L1S1 & 4.47 & 430 \\
L1G1 & -2.9 & 1350 \\
L1G2 & -2.86 & 810 \\
L2S1 & -0.8 & 610 \\
L2G1 & -2.97 & 520 \\
L2G2 & -0.67 & 1020 \\
L3S1 & 3.13 & 430 \\
L3G1 & 4.85 & 430 \\
L4S1 & 4.63 & 390 \\
\hline
\end{tabular}

the points L3G1 and L3S1 above $430 \mathrm{mS} / \mathrm{cm}$ but, due to $(22 \%)$ dilution from fresh water this increase in salinity is not seen at L3S1.

Groundwater sampled at L2G1 has $d^{18} \mathrm{O}$ $\sim-3.0 \%$ which is much depleted than L3G1. If it is formed through surface water body (similar to L3G1 but with surface source of $d^{18} \mathrm{O} \sim-3.0 \%$ ) then its salinity would have been much lower than $430 \mathrm{mS} / \mathrm{cm}$. Therefore, it can only be interpreted as the groundwater formed due to recharge from local precipitation. Thus, $\mathrm{EC}=430 \mathrm{mS} / \mathrm{cm}$ and $\mathrm{d}^{18} \mathrm{O}=$ $-2.97 \%$ o can be taken in the study area as fresh recharged groundwater due to precipitation. 
$\mathrm{d}^{18} \mathrm{O}$ of L2S1 $(=-0.8 \%$ ) is substantially enriched with respect to $\mathrm{d}^{18} \mathrm{O}$ of L2G1 (= $-2.97 \%$ ). Such an enrichment is expected to increase salinity of L2S1 close to $1000 \mathrm{mS} / \mathrm{cm}$ as similar to L2G2 which has similar $\mathrm{d}^{18} \mathrm{O}(=-0.7 \%$ ). But EC of L2S1 is much lower $(610 \mathrm{mS} / \mathrm{cm})$. The decrease in salinity can only be explained by fresh water addition through precipitation or due to link with L4 or L3.

Surface water at L1S1 $\left(\mathrm{d}^{18} \mathrm{O}=4.47 \%\right.$ ) if linked directly to $\mathrm{L} 2 \mathrm{~S} 1\left(\mathrm{~d}^{18} \mathrm{O}=-0.80 \%, \mathrm{EC}=610 \mathrm{mS}\right.$ / $\mathrm{cm}$ ) then its $E C$ is expected to be $>610 \mathrm{mS} / \mathrm{cm}$. But, EC of L1S1 is $430 \mathrm{mS} / \mathrm{cm}$. This explains that water body L1S 1 is getting filled directly through precipitation and may be to minor extent the surface run-off from upper reach water bodies. Moreover it is not linked to nearby groundwater. Otherwise, L1G1 would also have similar $\mathrm{d}^{18} \mathrm{O}$ and $\mathrm{EC}$ as that of L1S1.

L1 G2 has $d^{18} \mathrm{O}$ very similar to L1G1 but, its $\mathrm{EC}(=810 \mathrm{mS} / \mathrm{cm})$ is much lower than EC at L1G1. This suggest washout of groundwater salinity of L1G2. Thus, groundwater at L1G2 is expected to get recharged in its northwest region that is flushing the local salinity and discharging as base flow into the lake L1.

\section{CONCLUSION}

The lake water appears to get enriched in its isotopic composition mainly due to evaporation in this region. Lake water salinities are lower compared to nearby groundwater salinity. The flow of groundwater, recharged at Nittur lake, continues to its downstream at least till Pura. Increase in salinity of groundwater is seen between the points Pura-groundwater \& surface water (may be due to dissolution of sub-surface soil). The groundwater sampled at Belavatta is found to be recharged from local precipitation and not from surface body. The water body (Kadaba) is getting filled mainly due to precipitation and to some extent due to runoff from the upper reach of water body. There is a strong link between lake water-groundwater (e.g., site Pura) and groundwater-lake water (e.g. Site Kadaba).

Therefore, this procedure is expected to radically increase the accountability of usage and help in planning of suitable ground water supply and would provide a holistic approach to promote maximum agricultural output and industrial growth.

\section{ACKNOWLEDGEMENT}

Authors thank Director, National Institute of Hydrology, Roorkee for his support and encouragement.

\section{REFERENCES}

1. Krishan, Gopal and Rao, M.S. "Isotope Hydrology" Lambert Publishing House, Germany, pp 513 (2013).

2. Debnath, Palash, Mukherjee, Abhijit, Rao, M.S., Krishan, Gopal. Stable isotope signature of groundwater-seawater interaction in a micro-tidal coast of the Bay of Bengal. In: AGU-2014, Fall Meeting, San Francisco, 1519; (2014).

3. Debnath, Palash, Mukherjee, Abhijit, Rokade, Pramod, Joshi, Gopal, Rao, M.S., Krishan, Gopal. Stable isotopes and major ion chemistry of discharging groundwater to the Bay of Bengal: implications to strontium flux. In: Goldschmidt-2015, Prague, Czech Republic, 16-21 August, 2015. p. 681 (2015).
4. Krishan, Gopal, Rao, M.S., Kumar, C.P. and Semwal, Prabhat, G.S. Identifying Salinization Using Isotopes and ionchemistry in Semi-Arid Region of Punjab, India. Journal of Geology and Geosciences 2:129 (2013). http://dx.doi. org/10.4172/jgg.1000129

5. Krishan, Gopal, Rao, M.S., Kumar, C.P., Kumar, Sudhir, Rao, M. Ravi, Anand. A study on identification of submarine groundwater discharge in northern east coast of India. Aquatic Procedia. 4: 3-10 (2015).

6. Krishan, Gopal. Environmental tracer techniques in groundwater investigations. Water and Energy International. 58(7): 57-63 (2015).

7. Krishan, Gopal, Singh, Surjeet, Sharma, 
Anupma, Sandhu, C., Grischek, T., Gurjar, Suman, Kumar, Sumant, Singh, R.P., Glorian, $H$. and Bornick, H. Assessment of river quality for river bank filtration along Yamuna River in Agra-Mathura districts of Uttar Pradesh. International Journal of Environmental Sciences. 7(1): 56-67 (2016a).

8. Krishan, Gopal, Singh, Surjeet, Sharma, Anupma, Sandhu, C., Singh, R.P. and Kumar, Sumant. 2016b. Tracing Yamuna River Water Component in Groundwater using Isotopes in Agra-Mathura area of UP, India In: Proceedings of International conference and Exhibition on Innovative technologies and field applications for Sustainable water, wastewater \& energy management-SWWEM-16, during 17-19 August, 2016 IISC, Bangalore.

9. Kumar, Bhishm; Rai, S. P.; Krishan, Gopal and Rawat, Y. S. 2011. Identification of recharge areas and sources of springs in mountainous region using environmental isotopes. In: Drinking Water: Source, Treatment \& Distribution. Edited by Rajendra Dobhal, Thomas Grischek, H.P. Uniyal, D.P. Uniyal and C. Sandhu, Bishen Singh Mahendra Pal Singh, 2011, vii, 135 p, ISBN : 8121108133.

\section{8: 61-74.}

10. Purushothaman, P., Rao, M. S., Rawat, Y. S., Kumar, C.P., Krishan, Gopal and Parveen, T. Evaluation of hydrogeochemistry and water quality in Bist-Doab region, Punjab, India. Environmental Earth Sciences, 72: 693-706 (2013). DOI 10.1007/s12665-013-2992-9

11. Craig, H., and L. I. Gordon, Deuterium and oxygen 18 variations in the ocean and marine atmosphere. In proc. Stable Isotopes in Oceanographic Studies and Paleotemperatures, 1965, Spoleto, Italy. edited by E. Tongiogi, pp 9-130, V. Lishi e F., Pisa (1965).

12. Sakai H. and Matsubaya 0. (1977) "Stable Isotopic Studies of Japanese Geothermal systems: Geothemics, 5: pp.97-124.

13. Rao, M.S., Sampath Kumar, L, Rangaraj, C., Krishan, Gopal and Kumar, C.P. Tracing lake water component in the groundwater in parts of Tumkur district of Karnataka using isotopes. In: Proceedings of an International conference "India Water Week 2013-Efficient Water Management: Challenges and Opportunities" (IWW-2013), 08-12 April 2013 at New Delhi, India. Pp. 273 (2013). 